\title{
Erratum
}

\section{The chemopotentiation of cisplatin by the novel bioreductive drug AQ4N}

\section{R Gallagher, CM Hughes, MM Murray, OP Friery, LH Patterson, DG Hirst and SR McKeown*}

British Journal of Cancer (2002) 87, 1339. doi:I0.1038/sj.bjc.660056I www.bjcancer.com

(c) 2002 Cancer Research UK

Correction to: British Journal of Cancer (2001) 84, 625-929.

doi:10.1054/sj.bjc.2001.1975

Unfortunately due to an error Figure 5 was reproduced incorrectly.

The correct version is printed below.

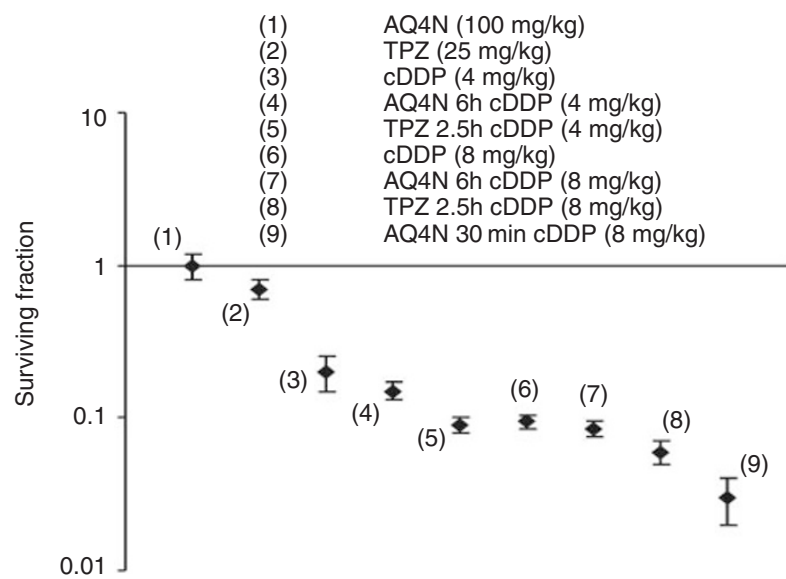

Figure 5 The effect of $A Q 4 N$ and TPZ on the bone marrow toxicity of CDDP. BDF mice were dosed i.p. with AQ4N (100 mg/kg) 30 min or $6 \mathrm{~h}$ prior to cDDP (4 or $8 \mathrm{mg} / \mathrm{kg}$ ). TPZ (25 mg/kg) was administered $2.5 \mathrm{~h}$ prior to cDDP (4 or $8 \mathrm{mg} / \mathrm{kg}$ ). The survival of bone marrow cells was assessed by the spleen colony assay. Results are means \pm S.E. for six mice. 